\title{
Hubungan Pola Makan Dengan Status Gizi Ibu Hamil Trimester III di Puskesmas Kuta Kecamatan Pujut Kabupaten Lombok Tengah
}

\author{
Hasrun Ningsih $^{1}$, Elly Sustiyani $^{1)^{*}}$, Nining Fatria Ningsih ${ }^{1}$, Fuji Khairani ${ }^{1)}$, Siti Maryam ${ }^{1)}$ \\ Email: ellysustiyani10@gmail.com \\ ${ }^{1)}$ Program studi DIII Kebidanan, Fakultas Kesehatan, Universitas Qamarul Huda Badaruddin
}

\begin{abstract}
ABSTRAK
Status gizi yang buruk pada ibu hamil bisa juga menyebabkan anemia yaitu suatu keadaan dimana kadar hemoglobin lebih rendah dari keadaan normal, dikatakan sebagai anemia bila keadaan hemoglobin kurang dari 11 gram \%. Anemia pada ibu hamil akan menambah resiko kelahiran bayi dengan Berat Badan Lahir Rendah (BBLR). Selain itu juga, anemia bisa menyebabkan resiko perdarahan sebelum dan pada saat persalinan yang dapat menyebabkan angka kematian ibu dan bayi. Tujuan penelitian adalah Penelitian ini di lakukan untuk mengetahui hubungan pola makan dengan status gizi pada ibu hamil trimester III yang berkunjung di Puskesmas Kuta. Metode penelitian jenis penelitian ini adalah observasional yang bersifat analitik dengan rancangan cross sectional, yaitu suatu penelitian untuk mempelajari dinamika korelasi antara pengetahuan dengan minat, dengan cara pendekatan, observasi atau pengumpulan data sekaligus pada suatu saat Populasi adalah keseluruhan objek penelitian atau objek yang diteliti 54 ibu hamil dan sampelnya Sampel pada penelitian ini adalah ibu hamil Trimester III. Hasil uji statistic dari hasil penelitian menyebutkan bahwa adahubungan antara

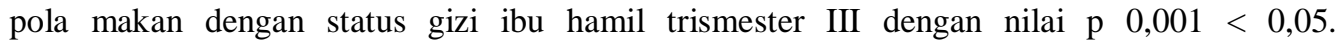
Kesimpulannya bahwa Ada hubungan yang signifikan antara pola makan dengan status gizi ibu hamil trismester III.
\end{abstract}

Kata kunci: Ibu Hamil, Trimester III, Gizi Ibu Hamil

\begin{abstract}
Poor nutritional status in pregnant women can also cause anemia in a condition where the hemoglobin level is lower than normal, it is said to be anemia if the hemoglobin state is less than 11 grams\%. Anemia in pregnant women will increase the birth of babies with Low Birth Weight (LBW). In addition, anemia can cause the risk of bleeding before and during childbirth, which can cause the death of the mother and baby. The purpose of this research is this research was conducted to see the relationship between diet and nutritional status of third trimester pregnant women who visit the Puskesmas Kuta. The research method of this type of research is observational analytic with cross sectional design, which is a study to determine the dynamics between knowledge and interest, by approaching, observing or studying data at once. The population is the whole object of research or the object under study 54 mothers pregnancy and the sample The sample in this study were trimester III pregnant women. The results of statistical tests from the results of the study indicate that there is a relationship between diet and nutritional status of pregnant women in trismester III with a p value of $0.001<0.05$. The conclusion is that there is a significant relationship between diet and nutritional status of pregnant women in trimester III.
\end{abstract}

Keywords: Pregnant woman, Third Semester, Nutrition of Pregnant Woman.

\section{A. LATAR BELAKANG}

Tujuan utama pembangunan nasional adalah meningkatkan kualitas Sumber Daya Manusia (SDM), yang di lakukan secara berkelanjutan berdasarkan uji pembangunan nasional melalui pembangunan kesehatan yang ingin dicapai untuk mewujudkan Indonesia sehat 2010. Visi pembangunan gizi adalah mewujudkan keluarga 
yang mandiri yang sadar gizi untuk mencapai status gizi yang optiamal diamana pembangunan seluruh masyarakat sangat tergantung pada keluarga yang menjadi bagian inti dari masyarakat [1]. Menurut survey Demografi Kesehatan Indonesia, Angka Kematian Ibu (AKI) di Indonesia sebesar 390 kematian per 100.000 kelairan hidup, diantaranya disebabkan karena pengaruh status gizi. Pada tahun 2003 AKI menunjukkan 307 per 100.000 kelahiran hidup, pada tahun 2005 menjadi 262 per 100.000 kelahiran hidup, pada tahun 2006 menjadi 255 per 100.000 kelahiran hidup. Sedangkan pada tahun 2007 berdasarkan hasil survey kesehatan rumah tangga AKI menunjukkan 248 per 100.000 kelahiran hidup diantaranya disebabkan karena pengaruh status gizi. Oleh karena itu pembangunan kesehatan dilakukan dengan prioritas pada upaya kualitas pelayanan kesehatan. Tingginya angka kematian ibu jika dibandingkan dengan target pencapaian MDG's, masih jauh dari harapan dalam komitmen global tersebut akan sulit dicapai . Tingginya angka kematian ibu di sebabkan antara lain seperti komplikasi saat persalinan, dan belum optimalnya layanan antenatal saat kehamilan [2]. Masih tingginya angka kematian pada ibu dan bayi salah satu penyebabnya akibat status gizi yang buruk pada ibu hamil. Adapun akibat dari status gizi yang buruk pada ibu hamil adalah KEK (Kurang Energi Kronis). Dampak dari hal tersebut adalah meningkatkan risiko bayi dengan berat badan lahir rendah, keguguran, kelahiran premature dan kematian pada ibu dan bayi baru lahir. Hasil survey menunjukkan bahwa prevalensi KEK (Kekurangan Energi Kronis) pada ibu hamil masih sangat tinggi, yaitu $51 \%$, dan pada ibu nifas $45 \%$ [3]. Status gizi yang buruk pada ibu hamil bisa juga menyebabkan anemia yaitu suatu keadaan dimana kadar hemoglobin lebih rendah dari keadaan normal, dikatakan sebagai anemia bila keadaan hemoglobin kurang dari 11 gram \% [4]. Anemia pada ibu hamil akan menambah resiko kelahiran bayi dengan Berat Badan Lahir Rendah (BBLR). Selain itu juga, anemia bisa menyebabkan resiko perdarahan sebelum dan pada saat persalinan yang dapat menyebabkan angka kematian ibu dan bayi [3].

Untuk pertumbuhan maupun aktivitas janin memerlukan makanan yang disalurkan melalui plasenta. Untuk itu ibu hamil harus mendapat gizi yang cukup untuk dirinya sendiri maupun bagi janinnya. Selama hamil ibu akan mengalami banyak perubahan dalam tubuhnya agar siap membesarkan janin yang dikandungnya, memudahkan kelahiran, dan untuk memproduksi ASI bagi bayi yang akan dilahirkannya [5]. Menurut Kartasapoetro [6], gizi adalah zat-zat yang diperoleh dari bahan makanan yang dikonsumsi dan mempunyai nilai yang sangat penting untuk memelihara proses tumbuh dalam pertumbuhan dan perkembangan, memperoleh energi guna melakukan kegiatan fisik seharihari, mengganti sel-sel yang rusak dan sebagai zat pelindung tubuh dengan cara menjaga keseimbangan cairan tubuh. Janin yang berkembang dan tumbuh di dalam kandungan mempunyai begitu banyak kebutuhan gizi yang harus dipenuhi melalui makanan yang harus dimakan oleh ibu hamil. Pola makan yang baik selama kehamilan dapat membantu tubuh mengatasi permintaan khusus karena hamil, serta memiliki pengaruh positif pada kesehatan bayi untuk menyusui dan mengasuh anak [7]. Hasil penelitian yang dilakuakan oleh Husaini, menunjukkan bahwa kenaikan berat badan pada trisemester pertama adalah $1,0 \mathrm{~kg}$, pada trisemester kedua $4,4 \mathrm{~kg}$, dan pada trisemester ketiga $6 \mathrm{~kg}$ ketiga [8]. Kenaikan berat badan dalam kehamilan disebabkan oleh hasil konsepsi berupa plasenta, fetus, liquor amnion dan dari ibu sendiri yaitu uterus dan mammae membesar, peningkatan volume darah, pertambahan protein dan lemak, serta terjadinya retensi darah. Kenaikan berat badan ibu hamil merupakan tolak ukur terhadap perkembangan status gizi ibu hamil. Dari studi pendahuluan yang penyusun laksanakan di Puskesmas Kuta Lombok Tengah terdapat 170 lebih ibu hamil yang berkunjung dalam 3 bulan terkhir ini. Ada sekitar 54 ibu hamil yang berkunjung pada bulan 
januari 2011. Dan sekitar $30 \%$ dari 54 ibu hamil tersebut memiliki ukuran lingkar lengan dibawah $23,5 \mathrm{~cm}$ atau sekitar 17 ibu hamil. Sebagian besar ibu hamil yang berkunjung memiliki status gizi cukup, dan pola makan ibu hamil sebagian besar 2 - 3 kali/hari. Dari latar belakang dan studi pendahuluan diatas maka peneliti tertarik untuk meneliti tentang hubungan antara pola makan dengan status gizi ibu hamil pada trimester III (tiga) yang berkunjung ke Puskesmas Kuta Lombok Tengah.

\section{B. METODE PENELITIAN}

Jenis penelitian ini adalah observasional yang bersifat analitik dengan rancangan cross sectional, yaitu suatu penelitian untuk mempelajari dinamika korelasi antara pengetahuan dengan minat, dengan cara pendekatan, observasi atau pengumpulan data sekaligus pada suatu saat (Point Time Approach). Dengan populasi 54 ibu hamil dan sampel yang digunakan semua ibu hamil Trimester III.

\section{HASIL DAN PEMBAHASAN}

\section{Hasil}

Tabel 1. Distribusi Responden Berdasarkan Umur Responden

\begin{tabular}{|l|c|c|}
\hline Umur & Frekuensi & $\%$ \\
\hline$<20$ Tahun & 2 & 4,2 \\
\hline $20-35$ Tahun & 46 & 95,8 \\
\hline$>35$ tahun & 0 & 0 \\
\hline Total & 48 & 100 \\
\hline
\end{tabular}

Tabel 1 diatas menunjukan data responden berdasarkan umur responden. Sebagian besar responden berumur antara 20 - 35 tahun yaitu sebanyak 46 responden (95.8\%), sedangkan yang berusia kurang dari 20 tahun sebanyak 2 responden $(4.2 \%)$.

Tabel 2. Distribusi Responden Berdasarkan tingkat Pendidikan

\begin{tabular}{|c|c|c|}
\hline Pendidikan & Frekuensi & $\%$ \\
\hline SD & 11 & 22.9 \\
\hline SMP & 8 & 16.7 \\
\hline SMA & 24 & 50.0 \\
\hline PT & 5 & 10.4 \\
\hline Total & 48 & 100.0 \\
\hline
\end{tabular}

Tabel 2 diatas menunjukan data responden berdasarkan pendidikan responden. Sebagian besar responden dengan pendidikan SMA (Sekolah Menengah Atas) yaitu sebanyak 24 responden $(50.0 \%)$, pendidikan SD (Sekolah Dasar) sebanyak 11 responden (22.9\%), pendidikan SMP (Sekolah Menengah Pertama) sebanyak 8 responden (16.7\%) dan pendidikan PT (Perguruan Tinggi) sebanyak 5 responden $(10.4 \%)$.

\section{Distribusi Responden Berdasarkan Pekerjaan}

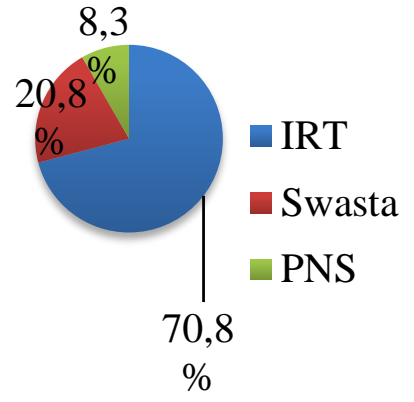

Gambar 1. Distribusi Responden berdasarkan Pekerjaan

Diagram Gambar 1 diatas menunjukan data responden berdasarkan pekrjaan responden. Sebagian besar responden dengan pekerjaan IRT (Ibu Rumah Tangga) yaitu sebanyak 34 responden $(70.8 \%)$, pekerjaan swasta sebanyak 10 responden $(20.8 \%)$ dan pekerjaan PNS (Pegawai Negeri Sipil) sebanyak 4 responden $(8.3 \%)$.

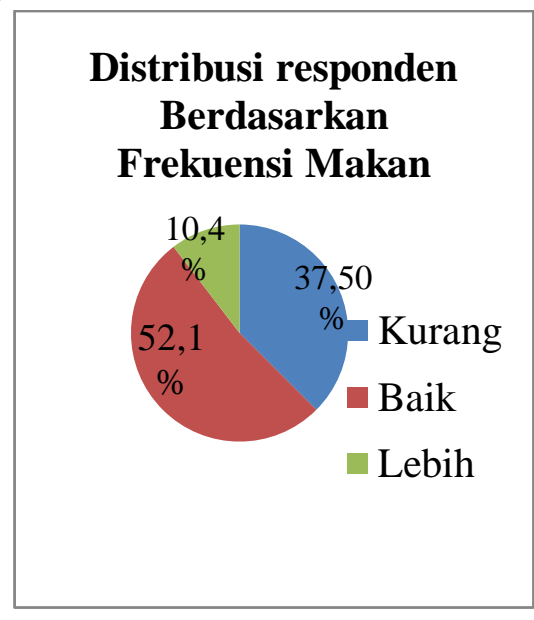

Gambar 2. Distribusi responden berdasarkan ferkuensi makan 
Diagram Gambar 2 diatas menunjukan data responden berdasarkan frekuensi makan. Sebagian besar responden dengan kategori frekuensi makan yang baik yaitu sebanyak 25 responden (52.1 \%), dengan kategori kurang sebanyak 18 rsponden (37.5\%) dan dengan kategori lebih sebanyak 5 responden (10.4\%).

Tabel 3. Distribusi responden Berdasarkan Kualitas Hidangan

\begin{tabular}{|c|c|c|}
\hline Kualitas & Frekuensi & $\%$ \\
\hline Baik & 32 & $66.7 \%$ \\
\hline Tidak Baik & 16 & $33.3 \%$ \\
\hline Total & 48 & $100.0 \%$ \\
\hline
\end{tabular}

Tabel 3 diatas menunjukan data responden berdasarkan kualitas hidangan. Sebagian besar responden dengan kualitas hidangan yang baik yaitu sebanyak 32 responden $(66.7 \%)$ dan dengan kualitas tidak baik sebanyak 16 responden (33.3\%).

Tabel 4. Distribusi Responden Berdasarkan

\begin{tabular}{|c|c|c|}
\hline \multicolumn{3}{|c|}{ Pola Makan } \\
\hline Pola Makan & Frekuensi & $\%$ \\
\hline Baik & 27 & $56.3 \%$ \\
\hline Tidak Baik & 21 & $43.7 \%$ \\
\hline Total & 48 & $100.0 \%$ \\
\hline
\end{tabular}

Tabel 4 diatas menunjukan data responden berdasarkan pola makan responden. Sebagian besar responden dengan pola makan yang baik yaitu sebanyak 27 responden (56.3\%) dan dengan pola makan tidak baik sebanyak 21 responden $(43.7 \%)$.

Tabel 5. Distribusi Responden Berdasarkan Status Gizi

\begin{tabular}{|c|c|c|}
\hline Status Gizi & Frekuensi & $\%$ \\
\hline Kurang & 16 & $33.3 \%$ \\
\hline Normal & 27 & $56.3 \%$ \\
\hline Lebih & 5 & $10.4 \%$ \\
\hline Total & 48 & $100.0 \%$ \\
\hline
\end{tabular}

Tabel 5 diatas menunjukan data responden berdasarkan status gizi. Sebagian besar responden dengan status gizi normal yaitu sebanyak 32 responden $(66.7 \%)$ dan status gizi yang kurang sebanyak 16 responden $(33.3 \%)$. Dalam penelitian ini menggunakan analisa Bivariat untuk mengetahui hubungan antara pola makan dengan status gizi ibu hamil trismester III. Oleh karena itu maka dilakukan analisis menggunakan Uji Chi-Square. Distribusi frekuensinya dapat dilihat pada tabel 6 dibawah ini.

Tabel 6. Distribusi Responden Berdasrkan Hubungan Pola Makan dengan Status Gizi Ibu Hamil pada Trimester III

\begin{tabular}{|c|c|c|c|c|c|}
\hline Pola & \multicolumn{3}{|c|}{ Status Gizi } & Total & Ket \\
\cline { 2 - 4 } Makan & Kurang & Normal & Lebih & & \\
\hline Baik & 4 & 19 & 4 & 27 & $\mathrm{X}^{2}=9.683$ \\
& $(14,8 \%)$ & $(70,4 \%)$ & $(14,8 \%)$ & $(100 \%)$ & $\mathrm{P}=0.008$ \\
\hline Tidak & 12 & 8 & 1 & 21 & \\
Baik & $(57,1 \%)$ & $(38,1 \%)$ & $(4,8 \%)$ & $(100 \%)$ & \\
\hline Total & 16 & 27 & 5 & 48 & \\
& $(33.3 \%)$ & $(56.3 \%)$ & $(10.4 \%)$ & $(100.0 \%)$ & \\
\hline
\end{tabular}

Distribusi responden berdasarkan hubungan pola makan dengan status gizi ibu hamil trimester III. Dristibusi responden dengan pola makan yang baik ada 27 responden sedangkan distribusi responden dengan pola makan tidak baik ada 21 responden. Dari total 27 responden yang mempunyai pola makan baik dan status gizi kurang ada 4 responden $(14,8 \%)$ dan yang mempunyai pola makan yang baik dan status gizi yang normal adalah 19 responden $(70,4 \%)$ dan yang mempunyai pola makan baik dengan status gizi lebih yaitu 4 responden (14,8\%). Dari 21 total responden yang mempunyai pola makan tidak baik ada 12 responden $(57,1 \%)$ yang mempunyai pola makan tidak baik dengan status gizi kurang, dan yang mempunyai pola makan tidak baik dengan status gizi normal ada 8 responden $(38,1 \%)$ dan yang mempunyai pola makan tidak baik dengan status guzi kurang adalah 1 responden $(4,8 \%)$

Dari hasil analisis dengan menggunakan uji Chi-Square, diperoleh nilai signifikasi 0.002 ( $\mathrm{p}<$ 0.05). Dari hasil tersebut diketahui bahwa $0.002<0.05$, sehingga dapat disimpulkan bahwa ada hubungan yang signifikan antara pola makan dengan status gizi ibu hamil trimester III.

\section{Pembahasan}

Berdasarkan hasil penelitian yang di lakukan oleh peneliti diketahui bahwa sebagian besar ibu hamil berusia antara 20 sampai dengan 35 tahun. Selain itu juga responden sebagian besar berpendidikan sekolah menengah atas (SMA), 
dari 24 responden yang lulusan SMA ada 22 responden yang mempunyai status gizi normal. Dilihat dari pekerjaan responden sebagian besar adalah IRT (ibu rumah tangga). Dari 34 responden yang berprofesi sebagai ibu rumah tangga ada 21 responden dengan pola makan yang baik. Pola makan ibu hamil adalah menu makanan yang dimakan ibu hamil dalam kesehariannya [9]. Pola makan sehat pada ibu hamil adalah makanan yang dikonsumsi oleh ibu hamil harus memilki jumlah kalori dan zat-zat gizi yang sesuai dengan kebutuhan atau memenuhi kualitas hidangan seperti karbohidrat, lemak, protein, vitamin, mineral, serat dan air[10]. Dalam pedoman umum gizi seimbang (PUGS) susunan makanan yang di anjurkan adalah yang menjamin keseimbangan zat -zat gizi. Hal ini dapat dicapai dengan mengkonsumsi beraneka ragam makanan yang baik secara kualitas maupun kuantitas setiap hari. Setiap makanan dapat saling melengkapi dalam zat-zat gizi yang di kandungnya. Adapun peran dan fungsi makanan pada ibu hamil adalah sebagai sumber energi dan tenaga yaitu untuk pembakaran tubuh, pembentukan jaringan baru. Sebagai zat pembangun yaitu diperlukan untuk pertumbuhan janin dan penggantian sel-sel yang rusak atau mati., dan sebagai sumber zat pengatur yaitu untuk melindungi tubuh dari serangan penyakit dan pengtur kelancaran metabolisme dalam tubuh ibu hamil [11]. Untuk mencapai gizi seimbang hendaknya susunan makanan sehari terdiri dari campuran ketiga kelompok bahan makanan tersebut. Dari setiap kelompok bahan makanan sebagai berikut sumber energi atau tenaga seperti bahan makanan yang mengandung karbihidrat, sebagai zat pengatur seperti bahan makanan yang mengandung air, mineral, vitamin (sayursayuran dan buah-buahan), dan sebagai sumber zat pembangun bagi ibu hamil adalah makanan yang mengandung lemak dan protein. Pada ibu hamil trimester III bahan makanan sumber zat pembangunan dan penyalur perlu di berikan lebih banyak untuk pertumbuhan janin [11]. Saat memasuki trimester III, pola makan harus disesuaikan dengan berat badan janin yang dikandungnya. Jika janin sudah memiliki berat cukup normal, maka ibu harus membatasi asupan makannya dan mulai sedikit melakukan diet karena pertumbuhan janin yang dikandung lebih cepat dibanding trimester sebelumnya. Meskipun orang hamil cenderung cepat merasa lapar, tetapi pola makan harus diatur agar bayi dalam kandungan perkembangan dan perkembangannya sesuai umur kehamilan. Pola makan diartikan sebagai informasi yang memberikan gambaran mengenai macam dan jumlah bahan makanan yang di makan tiap hari oleh satu orang dan merupakan ciri kelompok masyarakat tertentu [12]. Dalam penelitian ini pola makan dinilai berdasrkan 6 katagori golongan makanan yaitu golongan karbohidrat, protein, lemak, sayur, dan golongan minuman. Pada penelitian ini yang dilakukan menunjukan bahwa pola makan dengan kategori baik ada 27 responden, yang tidak baik ada sebanyak 21 responden. Hal ini menunjukkan bahwa pola makan yang baik dan mememnuhi kwalitas hidangan sangat diperlukan dan dibutuhkan bagi ibu hamil terutama pada saat memasuki trismester III agar gizi yang di perlukan oleh ibu hamil dan bayi terpenuhi. Menurut Almaitser [13] status gizi adalah keadaan tubuh sebagai akibat konsumsi makanan dan penggunaan zatzat gizi. Status gizi baik terjadi bila tubuh memperoleh cukup zat-zat gizi yang digunakan secara efisien, sehingga memungkinkan pertumbuhan fisik, perkembangan otak, kemampuan kerja dan kesehatan secara umum pada tingkat setinggi mungkin. Berdasarkan hasil penelitian menunjukan sebanyak 32 responden $(66.7 \%)$ dalam kategori status gizi yang normal, sedangkan yang kurang ada sebanyak 16 responden (33.3\%). Kecukupan gizi pada ibu hamil haruslah diperhatikan karena menyangkut kesehatan ibu hamil serta dapat berdampak pada perkembangan janin yang sedang dikandungnya. Status gizi adalah keadaan akibat dari keseimbangan konsumsi dan ssspenyerapan konsumsi dan penggunaan zat-zat gizi tersebut, atau keadaan fisiologik akibat 
tersedianya zat gizi dalam seluruh tubuh [14]. Pada masa kehamilan ibu hamil sangat memerlukan zat gizi yang lebih dari pada keadaan ibu yang tidak hamil. Semua zat gizi itu diperlukan untuk memelihara dan mempertahankan kesehatan ibu sendiri supaya dapat menyembuhkan luka pada saat persalinan dan nifas serta memberikan cadangan untuk masa laktasi dan pertumbuhan otak janin. Kebutuhan gizi maksimum terjadi pada mingguminggu mendekati kelahiran atau saat memasuki usia kehamilan 28 - 40 minggu (trimester III). Zat-zat gizi ini diperoleh janin dari simpanan dan dari makanan ibu sehari-hari pada waktu hamil. Kebutuhan gizi ibu hamil sangat penting dan harus mengandung energi yaitu karbohidrat, protein, lemak, air, dan sayuran yang baik bagi janin dan ibu hamil [15]. Hal tersebut mengindikasikan bahwa pengaturan pola makan yang baik pada ibu hamil dapat menentukan status gizi pada ibu hamil trismester III. Zat-zat gizi yang diperlukan ibu hamil untuk kesehatanya serta juga kesehatan dan perkembangan janin yang sedang dikandungnya harus diperhatikan dan dipantau. Kecukupan gizi dapat terpenuhi pada ibu hamil dengan pengaturan pola makan yang baik. Dari hasil penelitian menyebutkan bahwa adahubungan antara pola makan dengan status gizi ibu hamil trismester III.

\section{KESIMPULAN}

Berdasarkan hasil pembahasan diatas dapat disimpulkan sebagai berikut : Pola makan ibu hamil trimester III di Puskesmas Kuta Lombok Tengah dengan kategori baik sebanyak 27 responden. Status gizi ibu hamil trimester III di Puskesmas Kuta Lombok Tengah dengan kategori normal sebanyak 27responden. Ada hubungan yang signifikan antara pola makan dengan status gizi ibu hamil trismester III.

\section{DAFTAR PUSTAKA}

[1] Depkes RI. 2007. Peningkatan akses Masyarakat terhadap Pelayanan
Kesehatan\yang berkualitas. Departemen Kesehatan. Jakarta.

[2] Bappenas, 2008. Perbaikan Status Kesehatan dan Gizi Masyarakat.

[3] Depkes R.I. 2003. Pedoman Pemberian Besi Bagi Petugas, Depkes RI, Jakarta

[4] Manuaba, I. Bs. G. 2000. Kapita Selekta Penatalaksanaan Rutin Obstetri Ginekologi dan Keluarga Berencana, EGC, Jakarta.

[5] Erna Francin Paath, dkk, 2005. Gizi Tentang Kesehatan Refroduksi, FKUI: Jakarta.

[6] Marsetiyo \& Kartasapoetra, 2003. Ilmu Gizi Korelasi Gizi, kesehatan dan Produktifitas Kerja. Jakarta: Penerbit Rineka Cipta.

[7] Hannah.H.H. dan Rosemary D.2005.NCT Book Of Safe Foods. Jakarta

[8] Husaini, M, A. 1997. Analisis Data SKRT 1995. Anemia Pada Ibu Hamil. Jakarta: Puslitbang Gizi dan Badan Litbangkes Depkes RI.

[9] Prasetyono, D.S. (2009). Buku Pintar Asi Eksklusif. Yogyakarta: Diva press.

[10] Krisnatuti, Diah. 2004. Menyiapkan Makanan Pendamping Asi. Jakarta Puspa suara.

[11] Wariyana, 2010 Gizi Reproduksi :Pustaka Rihama, Sewon, Bantul, Yogyakarta

[12] Sri Kardjati, dkk. 1985. Aspek Kesehatan Gizi Anak Balita. Jakarta: yayasan Obor indonesia.

[13] Almatsier, S .2002. Prinsif Dasar Ilmu Gizi. Gramedia Pustaka Utama :Jakarta

[14] Supariasa, I. D. N. 2002. Penilaian Status Gizi. Jakarta: EGC.

[15] Sayogo, S. 2007. Gizi Ibu Hamil. Jakarta: Balai Penerbit FKUI. 